\title{
ORGANIZAÇÃO E ACESSO À INFORMAÇÃO NOS CORREIOS APÓS PROMULGAÇÃO DA LAI
}

Resumo: No período da Ditadura Militar (1964-1985), através do DecretoLei 200 é criado o Ministério das Comunicações e o serviço postal é retirado da área de viação e obras públicas e entra no mundo das comunicações. A Empresa Brasileira de Correios e Telégrafos é criada em 1969, como empresa pública de direito privado no âmbito da administração pública federal indireta. Este artigo tem como objetivo compreender como a cultura organizacional e o estatuto jurídico da empresa influenciam na organização da informação e na aplicação da Lei de Acesso à Informação. Caracteriza-se como uma pesquisa aplicada, de caráter descritivo, com uma abordagem qualitativa. As técnicas para coleta de dados foram pesquisa bibliográfica, análise dos pedidos de informação registrados no Sistema de Informação ao Cidadão, observação direta da autora, análise da legislação vigente e decisões administrativas disponíveis. Os resultados identificam a caracterização de regime híbrido como limitador ao acesso às informações pelo cidadão e a importância da organização da informação como instrumento de democratização do Estado.

Palavras-chave: Lei de Acesso à Informação. Organização da Informação. Empresa Estatal. Transparência Pública. Empresa Brasileira de Correios e Telégrafos.

\author{
Ana Maria de Almeida Ribeiro \\ Doutoranda do Programa de Pós-Graduação \\ em Ciência da Informação \\ Instituto Brasileiro de Informação em \\ Ciência e Tecnologia \\ ribeiro@acd.ufrj.br \\ Eliane Braga de Oliveira \\ Professora Doutora da Faculdade de Ciência \\ da Informação da UnB \\ elianebo@unb.br
}

\section{ORGANIZATION AND ACCESS TO INFORMATION IN THE POST OFFICE AFTER PROMULGATION OF LAI}

\begin{abstract}
The period of military dictatorship (1964-1985), through Decree-Law 200, is created the Ministry of Communications and the postal service is removed from the traffic area and public works and enters the world of communications. The Brazil Post is established in 1969 as a public company under private law under the indirect federal public administration. This article aims to understand how the organizational culture and the legal status of the company influence the organization of information and the application of the Law on Access to Information. It is characterized as descriptive applied research with a qualitative approach. The techniques for data collection were the literature, analysis of the inquiries recorded in the Information System Citizen, direct observation of the author, analysis of existing legislation and administrative decisions available. The results identify the characterization of the hybrid regime as limiting access to information by the citizen and the importance of information organization as a state democratization instrument
\end{abstract}

Keywords: Access to Information Law. Information Organization. State Company. Public Transparency. Brazil Post. 


\section{INTRODUÇÃO}

No dia 18 de novembro de 2011 a Presidenta Dilma Rousseff sancionou a Lei 12.527 (BRASIL, 2011c) que regula o acesso às informações como previsto no inciso XXXIII do art. $5^{\circ}$, no inciso II do $\S 3^{\circ}$ do art. 37 e no $\S 2^{\circ}$ do art. 216 da Constituição Federal. Após mais de duas décadas, a aprovação da Lei de Acesso à Informação (LAI) é considerada um passo relevante no caminho da consolidação da democracia no Brasil, ampliando a participação cidadã e fortalecendo os instrumentos de controle da gestão pública. O livre fluxo de informações e das ideias é crucial para o pleno exercício da democracia, efetivando o direito ao saber, ao conhecimento e à verdade, base para o efetivo respeito aos direitos humanos.

O livre fluxo de informações e ideias ocupa justamente o cerne da noção de democracia e é crucial para o efetivo respeito aos direitos humanos. Se o direito a liberdade de expressão - que compreende o direito de buscar, receber e transmitir informações e ideias - não é respeitado, não é possível exercer o direito ao voto, além das violações de direitos humanos ocorrerem em segredo, e de não haver como denunciar a corrupção e a ineficiência dos governos. É fundamental, para a garantia do livre fluxo das informações e das ideias, o princípio de que os órgãos públicos detenham informações não para eles próprios, mas em nome do povo. (MENDEL, 2009, p. 1).

A implantação da LAI no Brasil abrangeu todos os poderes da República (executivo, legislativo e judiciário) e todos os níveis de governo (federal, estadual e municipal). Iniciou sua implantação no poder executivo federal com a utilização de uma ferramenta tecnológica, através de um sistema de âmbito nacional, monitorado pela Controladoria Geral da União $(\mathrm{CGU})^{1}$. O sistema e-SIC, implantado em maio de 2012, e oficializado em 2015, através da Portaria Interministerial $\mathrm{n}^{\circ} 1.254$ (BRASIL, 2015) ${ }^{2}$, é o sistema centralizado para tratamento de pedidos de acesso à informação no âmbito do Poder Executivo Federal, onde o cidadão acompanha sua tramitação e respostas. Em 2011, a CGU anunciava os desafios colocados para a Administração Pública.

O desafio, agora, é assegurar a implementação desta Lei. Devemos enfrentar desafios de natureza técnica e tecnológica e também de caráter administrativo,

\footnotetext{
${ }^{1}$ A Presidenta Dilma foi afastada do cargo dia 12/05/2016 e neste mesmo dia o Vice-Presidente Michel Temer ao assumir temporariamente, por 180 dias, publicou a Medida Provisória 176, que extinguiu a CGU e criou o Ministério da Transparência, Fiscalização e Controle. O impedimento definitivo ocorreu em 31/08/2016 e a MP convertida em Lei $\mathrm{n}^{\circ}$ 13.341. Em $1 \%$ 1\%1/2019, através da MP 870 convertida em Lei $\mathrm{n}^{\circ} 13.844$, de $18 / 06$, voltou a ser CGU, como ministério e não mais vinculada à Presidência da República.

${ }^{2}$ Portaria Interministerial n ${ }^{\circ}$ 1.254, 18 de maio de 2015, publicada no Diário Oficial da União de 19/05/2015, institui o sistema e-SIC no âmbito do Poder Executivo Federal.
} 
que incluem a necessidade de recursos financeiros e humanos - estes, devidamente capacitados - para garantir a observância do que dispõe a Lei. Além disso, teremos que vencer a cultura do sigilo que, de forma silenciosa e invisível, ainda se constitui um dos grandes obstáculos para a abertura dos governos. (BRASIL, 2011a, p. 6).

A implantação da lei nas empresas estatais apresenta um diferencial com relação aos demais órgãos do poder executivo federal. Estas empresas têm um regime jurídico diferenciado, são instituições públicas, mas regidas pelo direito privado. Como empresas estatais, estão sujeitas aos controles públicos e comprometidas com objetivos coletivos, podendo ser prestadoras de serviços públicos ou exploradoras de atividades econômicas.

O Supremo Tribunal Federal (STF), nos debates a que tem sido chamado a se manifestar sobre as empresas estatais que prestam serviços públicos, as caracterizam como empresas submetidas a um regime híbrido.

Embora a rigor, as denominadas 'empresas estatais' ostentem a natureza jurídica de direito privado, elas se submetem a regime híbrido, ou seja, sujeitam-se a um conjunto de limitações que têm por escopo a realização do interesse público. Em outras palavras, no caso dessas entidades, ocorre uma derrogação parcial das normas de direito privado em favor de certas regras de direito público. (BRASIL, [2013], p. 42).

Para compreendermos a organização e o acesso à informação após promulgação da LAI na Empresa Brasileira de Correios e Telégrafos $(E C T)^{3}$, e as dificuldades em atender às solicitações de informações registradas pelos cidadãos, iremos analisar a estrutura do Estado brasileiro, em especial a administração indireta, no período de criação da empresa ECT e no período de implantação da lei; a organização da informação na empresa e como essa organização trouxe implicações no cumprimento da lei.

Identificaremos na administração indireta, na sua estrutura, e no seu respectivo corpo administrativo e técnico, os dilemas de atuação como órgão público na prestação de serviço público e nas atividades concorrenciais, e como consequência, os conflitos frente ao controle social. Não coincidentemente, são as empresas estatais (Correios, Petrobrás) que surgem nas manchetes dos jornais após ações de auditoria dos órgãos de controle, como Tribunal de Contas da União (TCU) e Controladoria Geral da União (CGU), com ocorrências de práticas administrativas que se confrontam com a legislação vigente para uso dos recursos públicos.

\footnotetext{
${ }^{3}$ No desenvolver desta pesquisa usaremos os termos "ECT" e "Correios" para identificar a Empresa Brasileira de Correios e Telégrafos, que já adotou a sigla EBCT, depois ECT e, desde 2014 vem utilizando a marca Correios.
} 
Para os fiscais, mídias e sociedade em geral, tudo indica corrupção, desvio de recursos públicos. Mas será que tudo é desvio do uso da coisa pública?

A partir da Constituição Federal de 1988 (CF) a gestão arquivística é fortalecida no país, através do $\S 2^{\circ}$ do art. 216. Segundo Fonseca (2013), sua regulamentação em 1991, através da Lei de Arquivos, Lei n ${ }^{\circ} 8.159$, contou com forte participação do Arquivo e foi um grande avanço para a gestão documental no país. Mas até que ponto a autonomia inserida no DecretoLei 200/1967 (DL200), e mantida no conjunto de arcabouço legislativo e normatizador, desde a ditadura militar, não permitiu essa independência e maior alinhamento ao mercado, não internalizando instrumentos de gestão pública do Estado democrático? Como dar acesso às informações da empresa pública se a mesma é caracterizada como hibrida, presta serviço público e explora atividade econômica, em nome do Estado no mercado concorrencial?

Dentre as mudanças introduzidas no regime militar, a criação do Ministério das Comunicações efetivou no Brasil o que já era uma realidade: a separação da comunicação dos transportes. Antes da invenção do telégrafo ${ }^{4}$ para transportar uma informação era necessário também transportar o meio de comunicação (o impresso, manuscritos etc.). O telégrafo permitiu que a mensagem viajasse sem a dependência dos mensageiros e dos transportes (animais, carroças, viaturas, navios, trens, aviões). Assim, um departamento da estrutura executiva de governo, o Departamento de Correios e Telégrafos (DCT), com funções operacionais, se transforma em uma empresa pública de direito privado, com funções estratégicas no controle da informação ${ }^{5}$.

A manutenção do serviço postal e do correio aéreo nacional estão presentes no Art. 21, inciso X, da CF (BRASIL, [1988]), e nos termos do artigo $9^{\circ}$, inciso I, da Lei n ${ }^{\circ} 6.538$ (BRASIL, 1978), em que está estabelecido que o serviço postal é explorado pela União em regime de monopólio, e é outorgado à ECT a execução de tais serviços. Segundo Teixeira (2013), o Decreto-Lei 509 (BRASIL, 1969), que transforma o DCT em ECT, enfatiza o caráter empresarial mudando sua vinculação ao Estado.

Em 2011, a Lei $\mathrm{n}^{\mathrm{o}} 12.490$ (BRASIL, 2011b) no art. 11, introduz aos serviços postais as atividades de logística, serviços financeiros e eletrônicos e aplica, subsidiariamente, a Lei $\mathrm{n}^{\mathrm{0}}$ 6.404 (BRASIL, 1976) que dispõe sobre as Sociedades por Ações. Recentemente, a Lei

\footnotetext{
${ }^{4} \mathrm{O}$ telégrafo é um aparelho para comunicação que utiliza eletricidade para enviar mensagens codificadas através de fios. Segundo a Escola Britannica, os dois primeiros a entrar em operação foram inventados por volta de 1830, na Grã-Bretanha e EUA. Disponível em https:/escola.britannica.com.br/artigo/tel\%C3\%A9grafo/482651. Acesso em 22.set.2019.

${ }^{5}$ O Departamento de Correios e Telégrafos (DCT) foi criado no Governo de Getúlio Vargas e era vinculado ao Ministério de Viação e Obras Públicas, pelo Decreto-Lei nº 200/1967, transforma em empresa e passa a ser vinculada ao Ministério das Comunicações.
} 
13.303 (BRASIL, 2016) ao dispor sobre o estatuto jurídico para as empresas públicas, fortalece a necessidade de transparência das empresas estatais. A nova lei estabelece a necessidade de regras de governança corporativa, de transparência e de estruturas, práticas de gestão de riscos e de controle interno, entre outros. Mudanças no Estado democrático que precisam de mudanças organizacionais.

Identificamos a Ciência da Informação (CI) como uma ciência que reflete sobre como deve ser sua interação com a sociedade e, como consequência, seu compromisso social, ao se dedicar ao estudo do ciclo de vida da informação - manuseio, armazenamento, transporte e descarte - para que sua recuperação seja possível para a concretização do acesso à informação pelo cidadão. Neste sentido, o Estado brasileiro, sua organização e a política de organização da informação, em especial a gestão documental nas instituições públicas, são elementos fundantes para atender às demandas da sociedade contemporânea por transparência pública, assegurando o efetivo exercício da cidadania e acesso rápido aos documentos e informações gerados pelo órgão e assim, fazem parte de nosso referencial teórico de estudo para o projeto.

Destacamos dois pedidos de informação, em especial, solicitados através do Serviço de Informação ao Cidadão (SIC). Os dois foram objeto de recursos junto à CGU, como exemplos de como a condição híbrida da ECT se reflete no atendimento ao acesso a informação e nos coloca o debate sobre Informação Pública e Transparência Ativa. O primeiro trata de cidadão que requer providências para disponibilização, em transparência ativa, da base de dados do Código de Endereçamento Postal (CEP). O segundo, o cidadão solicita os 100 maiores salários da Diretoria Regional do Paraná (DR-PR) com nome, matrícula e os respectivos salários, dos meses de novembro e dezembro de 2013.

Após a implantação da LAI em 2012, as atas dos colegiados passaram a estar disponíveis na página da empresa ${ }^{6}$ conforme orientação da CGU na implantação da lei, assim como, várias informações antes desconhecidas dos próprios empregados e do conjunto da sociedade brasileira. O levantamento destas informações para compor a página de Transparência da ECT foi o maior desafio nesse processo, e confirmam Araújo Júnior, Sousa e Albuquerque (2015, p. 45) “o maior entrave ao pleno acesso à informação não são as poucas restrições impostas pela Lei, mas a condição de organização da informação pública".

Apesar da farta literatura sobre a implantação da LAI no Brasil, foram poucos os trabalhos identificados que abordam as empresas estatais e a LAI quando da pesquisa no âmbito

\footnotetext{
${ }^{6}$ Disponível em http://www.correios.com.br/sobre-os-correios/a-empresa/publicacoes/atas-de-reunioes. Acesso em 21.set.2019.
} 
da dissertação de mestrado da autora (RIBEIRO, 2016). A publicação de estudos que tratam da implantação da lei de acesso nos órgãos públicos de direito privado, como as empresas públicas, é uma lacuna nesta experiência de governança e de instrumentos de controle social sobre o Estado. A ECT tem uma relevância social pela sua importância na política de informação e comunicação do país, e por ser uma experiência que pode estimular uma maior transparência e democratização das empresas públicas brasileiras. Com o objetivo de compreender como a cultura organizacional e o estatuto jurídico da empresa influenciam na organização da informação e na aplicação da Lei de Acesso à Informação, este trabalho espera contribuir com a sociedade brasileira no controle social das empresas públicas e na sua sustentabilidade.

\section{A ORGANIZAÇÃO DO ESTADO BRASILEIRO}

Jardim (1999, p.33) nos traz a importância de analisar o Estado e Hegemonia em Gramsci, onde o primeiro é compreendido como "todo o complexo de atividades práticas com a qual a classe dominante não somente justifica e mantém seu domínio, mas procura conquistar o consentimento ativo daqueles sobre os quais exerce sua dominação" (GRAMSCI, 1971 apud CARNOY, 1990, p.82). Assim, para Gramsci a estrutura e superestrutura formam um "bloco histórico", o conjunto complexo, contraditório e discordante das superestruturas, que é o reflexo do conjunto das relações sociais de produção. (1979, p. 71)

Bourdieu (2014, p.30) trata o Estado como "monopólio da violência física e simbólica", identificando-o como setor do campo do poder administrativo ou da função pública, em que se exerce a violência sobre a sociedade, desmistificando a ideia de Estado neutro e destacando os conflitos entre público e privado. Esses conflitos, no caso do Estado brasileiro, estão presentes no Decreto-Lei 200 (BRASIL, 1967) e nas reformas administrativas (BRESSER-PEREIRA, 1996; 1998).

Para Gramsci, ao se introduzir uma nova moral conforme uma nova concepção de mundo introduz-se também esta concepção, determinando uma reforma filosófica total. Neste sentido é que o autor afirma: "a estrutura e as superestruturas ${ }^{7}$ formam um bloco histórico, o conjunto complexo, contraditório e discordante das superestruturas, é o reflexo do conjunto das relações sociais de produção" (GRAMSCI, 1979, p.71)

\footnotetext{
${ }^{7}$ Nota da autora: estrutura (as relações sociais de produção) e superestrutura (as ideias, os costumes, os comportamentos morais, a vontade humana).
} 
Segundo Cury (2006, p.16) o período da Revolução Industrial (séculos XVIII e XIX) ocasionou "mudanças na sociedade europeia e americana, com reflexos em todo mundo ocidental". Cury (2006) enfatiza ainda que, sem o estudo deste período, fica difícil o entendimento das raízes do desenvolvimento capitalista atual, em que o fortalecimento dos Estados nacionais contribuiu para a eclosão dos conflitos mundiais do século XIX. Ao analisar a história da industrialização, a autora apresenta os modelos alemão, japonês, americano e inglês, suas diferenças e o papel do Estado em cada uma delas. A identificação desses modelos influenciará, no século XX, o tardio desenvolvimento industrial brasileiro e a opção pelo modelo de empresas estatais, adotado inclusive para os Correios do Brasil em 1967.

A organização do Estado brasileiro é, portanto, um tema bem complexo. Nogueira (2011, p. 19) destaca que a República brasileira nasceu de uma proclamação militar em 1889 e após um intervalo de quase quarenta anos, controlada por "oligarquias civis quase antirrepublicanas, hostis à nação, ao Estado e à cidadania", voltaria a se reencontrar com as Forças Armadas nos anos de 1930. Portanto, para o autor o golpe militar de 1964 seria a volta as raízes da vida nacional. Por longos vinte anos o país viveu sob o patrocínio do regime militar nascido em 1964 e até o reencontro com a democracia, "a eleição indireta de Tancredo Neves em 1985, foi por iniciativa de um dos generais no poder, Ernesto Geisel”. Nogueira ao contribuir para a construção de um Estado para a sociedade civil, afirma que ainda nos reportamos ao período militar para "explicar algumas de nossas insuficiências, ainda a responsabilizamos por muitos problemas da vida republicana atual”, o que é extremamente útil para compreender o desenvolvimento do capitalismo e o cenário de implantação da LAI no Brasil.

Esta complexidade pode ser melhor identificada se compreendermos o Estado brasileiro não apenas como um aparelho repressivo da burguesia, mas também como um instrumento de hegemonia da classe dominante. Jardim (1999), destaca que a classe dominante não depende apenas do seu poder econômico ou coercitivo, ela compartilha seus valores sociais, culturais e morais persuadindo, assim, os dominados a aceitarem suas crenças.

Na segunda metade do século XX, com a publicação da Declaração Universal dos Direitos Humanos em 1948 (ORGANIZAÇÃO DAS NAÇÕES UNIDAS, 2009), se abre um período de defesa do Estado democrático, expresso pelo direito à liberdade de opinião e expressão, que inclui a liberdade de procurar, receber e transmitir informações e ideias, por quaisquer meios e independente de fronteiras. No hemisfério Sul do mundo, particularmente no Brasil, “apenas nas últimas duas décadas do século XX a ideia de participação na gestão pública 
passou a estar presente", refletindo, por um lado, o avanço da democratização e da diferenciação social e, por outro, o aumento da valorização da democracia participativa (NOGUEIRA, 2011, p. 121).

Segundo Bresser-Pereira (1996, p. 7), a partir do pressuposto da "rigidez da administração direta e da maior eficiência da administração descentralizada" toda a ênfase foi dada à descentralização, mediante "autonomia da administração indireta". Entretanto, reconhece o autor que isso teve duas consequências "inesperadas e indesejáveis". Ao permitir a contratação de pessoal sem concurso público, Bresser-Pereira afirma que essa pratica facilitou a sobrevivência de práticas "patrimonialistas e fisiológicas" e, por outro lado, não houve preocupação com as "mudanças no âmbito da administração direta e central". O autor salienta, ainda, que na medida em que se inicia a crise política do regime militar, já nos anos 1970, se agrava a situação da administração pública brasileira em que a burocracia estatal é identificada com o sistema autoritário em pleno processo de degeneração.

Para Klering, Porsse e Guadagnin (2010, p.5) a disposição para "reformar administrativamente" o Estado brasileiro era antiga, presente desde a década de 1930 e assumiu maior relevância em meados da década de 1990, pela institucionalização da Lei da Reforma do Estado Brasileiro. Segundo os autores, no governo Lula (2003-2010), em contraposição as reformas do Estado anteriormente propostas, as ações foram voltadas para um "Estado promotor da inclusão social”, (KLERING; PORSSE; GUADAGNIN, 2010, p.9).

Ao situar o Estado brasileiro, que recepciona a Lei de Acesso à Informação em 2011, identificamos a necessidade de um Estado para a sociedade civil que "recupere o Estado para a sociedade e que o coloque numa escala superior de valorização e de relevância" (NOGUEIRA, 2011, p. 80), a partir do "Estado Herdado" das décadas de ditadura militar passando pelo neoliberalismo, e a tentativa de construção do "Estado Necessário" (DAGNINO, 2013, p. 101102).

Por fim, como afirma Mendel (2009) é fundamental, para a garantia do livre fluxo de informações e ideias, que os órgãos públicos tenham claro que as informações que detém não são para eles próprios, mas para o cidadão, e são o cerne da noção de democracia.

A democracia também implica prestação de contas e boa governança. O público tem o direito de perquirir os atos de seus líderes e de participar de um debate pleno e aberto sobre tais atos. Precisa ser capaz de avaliar o desempenho do governo, o que depende do acesso à informação sobre o estado da economia, sistemas sociais e outras questões de interesse público. Uma das 
formas mais eficazes de atacar a má governança, sobretudo com o passar do tempo, é por meio do debate aberto e bem informado. (MENDEL, 2009, p. 5).

Segundo Nogueira (2011, p. 79), sem um Estado "vigoroso, democrático e socialmente vinculado não há como ter uma articulação virtuosa entre governabilidade, desenvolvimento, igualdade e justiça social".

Portanto, a discussão da organização do Estado brasileiro e da manutenção do DecretoLei $n^{\circ} 200$ (BRASIL, 1967), são de vital importância para o fortalecimento dos princípios democráticos expressos na Carta Magna de 1988, no interior dos órgãos e entidades públicas. Os dilemas e entraves para a transparência pública residem, no caso da Administração Indireta (autarquias, fundações, empresas estatais e sociedade mista) no grau de autonomia conferido no regime militar e sua relação com a sociedade, de controle social, expressa na CF.

\section{DO SIGILO AO DIREITO À INFORMAÇÃO}

Para Zepeda (2012, p. 12) ${ }^{8}$, “o homem que está livre das correntes e contempla a realidade é, naturalmente, o filósofo", entretanto o autor identifica que para Platão o homem é também o político, o único capaz de entender o que é bom, a verdade para além de "todas as aparências e toda opinião”. O conhecimento das verdades da prática política é, portanto, segundo Zepeda (2012), reservado para aqueles participantes da "aristocracia do intelecto", que podem transcender o preconceito e a ignorância da população. Este é o sentido de justiça que para o autor está na origem dos arcana imperii ${ }^{9}$, isto é, dos segredos do poder que estabelecem por dentro e por fora do poder político e, portanto, hierarquizam as pessoas com relação à prática política e a qualidade dos conhecimentos e argumentos que podem ter à sua disposição. Bobbio (2015) ao tratar do Estado absoluto, que em sua doutrina tem os arcana imperii como tema recorrente, no qual o poder autocrático oculta ou mente considerando isso um ato lícito de governo, reafirma que a opacidade do poder é a negação da democracia.

\footnotetext{
${ }^{8}$ Tradução livre da autora.

${ }^{9}$ Foi o grande historiador romano Tácito (55-120), o primeiro que denominou arcana imperii esses pedaços de conhecimento, esses mistérios da política. Arcana (de raiz indo-européia: arek) significa segredo, algo que é retido ou que se guarda. Mas arcana imperii não só se refere aos segredos do império ou do estado, mas a verdades que possuem um significado quase sagrado, ritual, ou seja, mistérios insondáveis da política. Porque os arcana imperii não se reduzem a condição de informações plenas sobre questões públicas, mas para selecionar, informações privilegiadas, que define o poder como o sujeito de quem detém e administra. (ZEPEDA, 2012, p. 15).
} 
Segundo Baracchini (2008, p.120), a Ditadura Militar (1964-1985), impôs ao país a partir de 1964, o fim do regime democrático, e "instaurou uma ordem frontalmente diversa da democrática" vigente desde 1945, trazendo a opressão, a repressão e a depressão, e com isso, o sigilo. Ao analisarmos a cultura do sigilo buscamos identificar os aspectos que irão impactar na administração pública dos Correios, tendo em vista o direito ao acesso à informação como princípio da LAI.

Jardim (1999, p.85/86) identifica este período como o de um distanciamento do Estado brasileiro da sociedade civil, de uma "forte centralização no Governo da União" e "marcadamente autoritário, acirra a concentração de renda e os desajustes sociais". A criação de órgãos como o Serviço Nacional de Informação (SNI), o Departamento de Operações e Informações do Exército (DOIEx), o Centro de Informações do Exército (CIEx), Centro de Informações da Marinha (CIM), entre outros, e o fortalecimento do Departamento de Ordem Política e Social (DOPS) em todos os estados brasileiros, demonstram o controle do Estado da informação.

Carvalhêdo e Rodrigues (2008, p. 2) apontam que as políticas de informação do Estado brasileiro adotadas a partir do Regime Militar estão relacionadas à Guerra Fria, "período de disputa travada entre os Estados Unidos e a então União Soviética com um forte componente ideológico internacional contra e pró-comunista", estimulando a propaganda cultural e a criação de instituições de informação estatais.

O papel do aparato repressivo desenvolvido pela Ditadura Militar, legalizado através do Ato Institucional 1 (AI-1) e da doutrina de Segurança Nacional, permitiu que a violação de correspondência fosse uma das atividades desses órgãos para repassar informações ao SNI, como afirma Fernandes (2009).

Cabia ao CIEx repassar as informações para o SNI, que depois as irradiavam para os órgãos de repressão direta. Para obter as informações desejadas sobre os exilados, esse centro de espionagem recorria a vários métodos: infiltração de agentes no meio dos exilados, violação de correspondência, rastreamento de veículos considerados suspeitos que circulavam pela fronteira, controle das atividades e dos "pombos-correios" dos principais líderes da esquerda, etc. (FERNANDES, 2009, p. 6, grifo nosso).

O serviço postal sempre esteve sujeito a restrições e proibições dos governantes que determinavam a circulação e distribuição das correspondências. A censura postal no Brasil foi oficialmente instituída em 1917, no período da $1^{\text {a }}$ Guerra Mundial (1914/1919) e teria sido 
abolida em 1948, mas há comprovações ${ }^{10}$ de que houve censura postal em vários outros períodos da história, como durante a ditadura militar.

A cultura do sigilo também se manifesta através de outros mecanismos dentro da empresa estatal. Teixeira (2013, p. 43) ao analisar a organização do trabalho no contexto da ditadura militar nos Correios, descreve as ações com a lógica militar que foram implantadas e, nesse contexto, as intervenções gerenciais tiveram como objetivo "a adoção de métodos de gestão focados no controle, disciplina e racionalização da força de trabalho". Segundo o autor, as ações de autoritarismo e repressão foram uma constante durante décadas na empresa consolidando práticas de segredo e silêncio no interior da estatal, cristalizando a cultura do sigilo no ambiente organizacional.

Para Jardim (1999, p.49) o acesso à informação governamental, encontra, "a partir dos anos 1970, em Estados de características democráticas, diversas formas de expressão", que o autor traduz como duas noções relacionadas: "transparência administrativa e direito à informação". Para o autor a noção de transparência administrativa tomada como um dos requisitos de controle da sociedade civil sobre o Estado, vai encontrar lugar em diversos discursos dos atores envolvidos na zona de tensão que decorre das relações entre ambos.

O direito de acesso à informação aparece no âmbito da defesa à liberdade de expressão que pressupõe o acesso a fontes íntegras e plurais de informação. (CUNHA FILHO; XAVIER, 2014, p. 13).

Segundo Malin (2012), antes do Brasil, vários países já haviam adotado leis que regulam o procedimento de acesso às informações públicas, sendo a Suécia o primeiro país em 1766.

A aprovação da Lei n ${ }^{0} 12.527$ - Lei de Acesso à Informação (LAI) - no Brasil representa a adesão do país a um novo regime de informações, mais precisamente, ao regime jurídico de direito à informação pública que vem se manifestando globalmente através de leis nacionais e supranacionais, com força restruturante da ordem social e política brasileira a ser monitorada e estudada. (MALIN, 2012, p.2).

Assim, a partir da implementação da LAI no Brasil, assistimos ao começo da construção do que Malin e Freitas (2018, p.10) consideram a "consolidação do regime institucional de informação", e apresentam a relação de marcos regulatórios e normativos que

\footnotetext{
${ }^{10}$ Não localizamos referências bibliográficas, apenas o registro do filatelista Rubem Porto Jr com seu acervo apresentado em vídeo. (PORTO JR, 2014).
} 
passaram em que princípios, normas, regras e procedimentos relativos à informação que circulam entre o Estado e a sociedade civil.

\section{A CIÊNCIA DA INFORMAÇÃO E A TRANSPARÊNCIA PÚBLICA}

Araújo (2014, p. 104-105) analisa o surgimento da Ciência da Informação (CI) e destaca a atuação dos primeiros cientistas a partir das primeiras décadas do século XX, no Reino Unido e depois nos Estados Unidos da América, até a realização de dois encontros no Georgia Institute of Technology, "considerados importantes na consolidação da ciência da informação na década de 1960".

O reconhecimento da CI como ciência é um debate importante no qual Brookes (1980, p.125) identifica uma deficiência na elaboração teórica. O autor afirma que cada vez mais a Ciência da Informação "opera ativamente em um oceano de aplicações práticas de bom senso que cada vez mais envolvem o computador", mas encontra-se num "limbo filosófico".

A ciência como "categoria histórica, em constante evolução e ligada às necessidades, à vida e à atividade do homem", de acordo com Gramsci (1979, p.98), é o elo para entender a CI como uma ciência que deve ter sua interação com a sociedade e assim seu compromisso social.

Mandel (1982, p. 123) enfatiza que "toda a teoria do conhecimento é submetida a uma prova implacável: a prova da prática". Segundo o autor, o próprio conhecimento "não é um fenômeno separado da vida e dos interesses dos homens" compreendendo que o conhecimento nasceu da prática social do homem que tem por função aperfeiçoar esta prática.

Buscamos em Freire (1983, p. 15-16) o destaque do "compromisso radical das ciências sociais com o homem concreto que deve se orientar no sentido da transformação" e com isso concluir que a CI é uma ciência social com compromisso social. O autor afirma que a primeira condição para que um ser possa assumir um ato comprometido está em "ser capaz de agir e refletir". Portanto, para que a Ciência da Informação esteja comprometida, há necessidade que sua produção esteja vinculada com a ação e a reflexão. Esta reflexão, sobre si mesmo, sobre seu estar no mundo, associada indissoluvelmente à sua ação sobre o mundo, é o que possibilita transpor os limites que lhe são impostos pelo próprio mundo.

Wersig e Neveling (1975) introduzem mais explicitamente a responsabilidade social como fundamento da CI que, apesar de, no início do século XX, ser vista com cunho socialista 
e por isso renegada, nos anos 1970 passa a ser um campo de estudo decisivo para o crescimento e desenvolvimento das empresas " [...] atualmente, transmitir o conhecimento para aqueles que dele necessitam é uma responsabilidade social, e essa responsabilidade social parece ser o verdadeiro fundamento da CI.” (WERSIG; NEVELLING, 1975, p. 11).

A transparência é um dos compromissos sociais que estabelece um órgão governamental para possibilitar ao público que solicita a informação existente sobre um assunto público. Esta informação pode se apresentar de muitas formas diferentes e referir-se à aspectos diferentes de como a organização está tratando os assuntos públicos.

Rodrigues (2013, p. 424) remete aos anos 1970 quando surge o conceito de transparência, observando que seu "sentido político é decorrente do questionamento do modelo de administração tradicional ancorado na cultura do segredo", e que sua noção já está presente como "premissa para o bom funcionamento da Administração Pública".

Jardim $(1999$, p.49) destaca que a noção de transparência administrativa, em uma de suas leituras, é o de requisito de "controle da sociedade civil sobre o Estado". A transparência do Estado se expressa na possibilidade de acesso do cidadão à informação governamental como requisito fundamental. Para o autor, a opacidade informacional do Estado é a expressão e o mecanismo de produção de hegemonia da classe dirigente, instrumento de dominação e exclusão social.

O debate sobre o caráter híbrido da ECT passa pela discussão da atuação do Estado na ordem econômica enquanto empresa pública. Se o serviço postal assume a forma de um serviço público - inerente ou por opção político-normativa - ou, se se trata do desempenho de uma atividade econômica. Em 2009, o tema foi objeto de decisão do Supremo Tribunal Federal (STF) no julgamento da Arguição de Descumprimento de Preceito Fundamental (ADPF) 46, na qual a Associação Brasileira das Empresas de Distribuição reclamava o direito de as transportadoras privadas fazerem entregas de encomendas. Na votação do STF a Lei 6.538/78, que trata do monopólio dos Correios, foi admitida e considerada de acordo com a Constituição Federal de 1988. O voto do Ministro Carlos Ayres Britto foi de grande importância para o resultado final ao afirmar que "essa especificidade decorreria da destinação das atividades de que estamos a falar: favorecer a comunicação privada entre pessoas, a integração nacional e o sigilo da correspondência" (BRASIL, 2010, p. 112) e ao manifestar sua crença no "Estado como carteiro entre o emissor e o destinatário da mensagem" ${ }^{11}$.

\footnotetext{
${ }^{11}$ Disponível em https://stf.jusbrasil.com.br/noticias/1635382/stf-mantem-monopolio-dos-correios-para-correspondenciaspessoais. Acesso em 22.set.2019.
} 


\section{OS CORREIOS: A ORGANIZAÇÃO, O ACESSO À INFORMAÇÃO E A LAI}

A compreensão da transparência das informações públicas vem se ampliando a cada dia na sociedade brasileira. Entretanto, o que pouco se discute é o conceito de informação pública. Frohmann (2008, p.20) destaca a importância em "conciliar o conceito de informação com estudos das importantes práticas públicas e sociais, com o conceito de materialidade". O autor afirma que o conceito de materialidade é muito importante quando pesquisamos o que fazem os "sistemas de informação", entendendo-os no sentido amplo o que ele chama de regimes de informação. Para o autor, "documento" nomeia a materialidade da informação, e assim passa a ter um caráter público e social. Um documento público para ser um fato, ou ainda, um ato precisa da chancela de pelo menos um agente público com autoridade para instituir, formalizar ou legitimar aquele ato, aquele documento.

Em 1985, o Arquivo Nacional publicou um manual técnico sob o título "Orientação para avaliação e arquivamento intermediário em arquivos públicos", do qual constam diretrizes gerais para a realização da avaliação e para a elaboração de tabelas de temporalidade. Posteriormente, em 1986, iniciaram-se as primeiras atividades de avaliação dos acervos de caráter intermediário sob a guarda da, então Divisão de Pré-Arquivo do Arquivo Nacional, com a preocupação de estabelecer prazos de guarda com vista à eliminação e, consequentemente, à redução do volume documental e racionalização do espaço físico.

A organização e o acesso aos documentos públicos sempre estiveram presentes para os que preservam a importância da memória institucional e coletiva de um povo. A Constituição Federal foi um marco importante na garantia de conquistas sociais aos brasileiros, tendo no artigo 216, em seu parágrafo segundo, estabelecido a responsabilidade da administração pública sobre a gestão da documentação governamental e as providências para franquear sua consulta a quantos dela necessitassem. A gestão documental e o direito ao acesso à informação devem ser, portanto, destacados como conquistas deste período.

A Lei $n^{0} 8.159$ (BRASIL, 1991) é a regulamentação desta conquista constitucional, que dispõe sobre a política nacional de arquivos públicos e privados e é aprovada no contexto da gestão documental no Brasil. Entretanto, a estrutura dos Correios não internalizou de forma plena esses instrumentos. A cultura empresarial e sua autonomia frente ao Estado estavam expostas no Decreto-Lei 200/1967. 
Art. 27. Assegurada a supervisão ministerial, o Poder Executivo outorgará aos órgãos da Administração Federal a autoridade executiva necessária ao eficiente desempenho de sua responsabilidade legal ou regulamentar.

Parágrafo único. Assegurar-se-á às emprêsas públicas e às sociedades de economia mista condições de funcionamento idênticas às do setor privado cabendo a essas entidades, sob a supervisão ministerial, ajustar-se ao plano geral do Govêrno (BRASIL, 1967, grifo da autora).

O estabelecimento de procedimentos para a eliminação de documentos produzidos por instituições públicas e de caráter público, na referida legislação de arquivos públicos de 1991, estabelece que a mesma "será realizada mediante autorização de instituição arquivística pública, na sua específica esfera de competência”. A lei também preconiza a revitalização dos serviços arquivísticos do Poder Público por meio de programas de gestão de documentos, que reúnam procedimentos e operações técnicas referentes à produção, tramitação, uso, avaliação e arquivamento de documentos.

Segundo a, então, Gerência dos Processos de Gestão Documental (GDOC) da ECT houve uma "descontinuidade da gestão de documentos por processos na ECT." (RIBEIRO, 2016, p. 109). No decorrer da década de 1980 a empresa adotou os conceitos de formação de processos. Entretanto, por alguma razão, desconhecida dos profissionais, estes procedimentos "se perderam no tempo". A ECT é uma empresa pública com regime de trabalho CLT (Consolidação das Leis do Trabalho) e nestas empresas é muito comum a existência periódica de Programas de Demissão Voluntária. Com isso um conjunto valioso de empregados, com a memória institucional da empresa, desaparece sem nenhum planejamento organizacional, e sem a necessária gestão do conhecimento acumulado. Após algumas conversas, a tese mais plausível é a de que durante a década de 1990 algumas consultorias foram contratadas para a modernização da empresa e foi introduzido um modelo de gestão em que deveriam deixar as mesas limpas, sem papel. Com isso, documentos foram eliminados sem nenhum tipo de avaliação e coordenação (RIBEIRO, 2016). Os reflexos dessa ação se evidenciam no ano de 2005.

O Inquérito Civil no 1.16.000.000919/2005-09 foi instaurado em função de matéria jornalística com ampla divulgação nacional sobre um "esquema de corrupção" ${ }^{12}$ nos Correios, em 2005. O célebre vídeo no qual um executivo do quadro efetivo dos Correios aceita $\mathrm{R} \$ 3.000$, 00 (três mil reais) de um empresário que se diz interessado em "fazer negócios com a empresa

\footnotetext{
${ }^{12}$ Referente a matéria jornalística publicada pela revista veja, edição $\mathrm{n}^{\mathrm{o}} 1.905$ - ano 38 , de 18 de maio de 2005 , sobre um esquema de corrupção na área de licitações e contratos da Empresa Brasileira de Correios e Telégrafos (texto reproduzido do Termo Aditivo publicado no D.O.U. seção 3 n $^{\circ}$ 165, de 26/08/2011, pag.116).
} 
estatal" (LEITE, 2013, p.26). O que será conhecido nacionalmente como "Mensalão do Correios". Este inquérito resultou em um Termo de Ajuste de Conduta (TAC) assinado pela ECT e o Ministério Público Federal (MPF) em 21/10/2010, que trata dos procedimentos relacionados à fiscalização, autuação e arquivamento de processos de contratação e de gestão de contratos no contexto da Lei 8.666/1993 (BRASIL, 1993) e da Lei 9.784/1999 (BRASIL, 1999) $)^{13}$. A cláusula segunda do TAC determinava a necessidade de "Instrução, Autuação e Arquivamento dos documentos da ECT". Antes da assinatura do TAC, a definição dos prazos de guarda dos processos de contratação e de gestão de contratos na empresa, se dava pelas Instruções Normativas do Tribunal de Contas da União (TCU), as quais estipulavam os prazos prescricionais específicos para estes documentos, tomando-se por base eventos relacionados à decisão definitiva de julgamento das contas pelo TCU ou da apresentação, pelas unidades jurisdicionadas, dos relatórios de gestão ao TCU. De acordo com a gerente corporativa da GDOC, há um reconhecimento de que nas últimas três décadas a empresa não conseguiu "recepcionar de forma plena a legislação que tratava da gestão documental” no país (RIBEIRO, 2016, p. 100).

Os Correios estabeleceram suas próprias regras e prazos de temporalidade dos documentos, distante do publicado pelo órgão arquivístico. O TAC refletiu em mudanças importantes na empresa.

Através de Comunicação Interna Circular (CI/PRESI 0325/2011) o Presidente dos Correios informa, a todos, do início de uma nova sistemática de gestão documental e de formação de processos administrativos, no dia 3/10/2011. A nova sistemática passou a ser adotada na empresa com o registro de protocolo de processos e a garantia de uma correta instrução e tramitação, com a adoção do NUP - Número Único de Protocolo, e com a implantação do Sistema de Gestão de Documentos Correntes - GDC, desenvolvido pelos empregados da empresa, e implantado de norte a sul do país. Na Tabela 1 podemos identificar o diagnóstico e as ações encaminhadas nos correios.

\footnotetext{
${ }^{13}$ Lei n ${ }^{\circ} 8666 / 93$ institui normas para licitações e contratos da Administração Pública e dá outras providências e a Lei no 9784/1999 Regula o processo administrativo no âmbito da Administração Pública Federal 
Figura 1 - Diagnóstico e Ações Gestão Documental ECT

\begin{tabular}{|l|ll|}
\hline \multicolumn{1}{|c|}{ Situação até 2011 } & \multicolumn{1}{c|}{ Consequências } & \multicolumn{1}{c|}{ Ações } \\
\hline $\begin{array}{l}\text { Inexistência de padrão } \\
\text { de procedimentos de } \\
\text { gestão documental }\end{array}$ & $\begin{array}{l}\text { Dispersão dos documentos } \\
\text { produzidos em virtude de } \\
\text { tramitarem de forma } \\
\text { independente (avulsa) }\end{array}$ & $\begin{array}{l}\text { Estruturação da } \\
\text { informação em forma de } \\
\text { processo administrativo em } \\
\text { toda empresa; }\end{array}$ \\
\hline $\begin{array}{l}\text { Tratamento } \\
\text { simultâneo do mesmo } \\
\text { assunto em vários } \\
\text { órgãos }\end{array}$ & $\begin{array}{l}\text { Insegurança na tomada de } \\
\text { decisões }\end{array}$ & $\begin{array}{l}\text { Implantação do Número } \\
\text { Único de Processo (NUP), } \\
\text { de acordo com a Portaria } \\
\text { SLTI/MPOG no 3/2003(6) }\end{array}$ \\
\hline $\begin{array}{l}\text { Falta de controle } \\
\text { sistematizado dos } \\
\text { documentos } \\
\text { produzidos }\end{array}$ & $\begin{array}{l}\text { Dificuldade no acesso à } \\
\text { informação e de sua } \\
\text { recuperação. }\end{array}$ & $\begin{array}{l}\text { Definição do GDC (Gestão } \\
\text { de Documentos Correntes) } \\
\text { como sistema corporativo. }\end{array}$ \\
\hline
\end{tabular}

Fonte: Informações da GDOC sobre a Sistemática de Formação de Processos - GDC/NUP.

Portanto, a organização da informação possibilitaria o cumprimento da Lei de Acesso a Informação, que seria implantada em 2012.

A LAI considera, no art. $4^{\circ}$, que informação são "dados, processados ou não, que podem ser utilizados para produção e transmissão de conhecimento, contidos em qualquer meio, suporte ou formato; e que documento é a unidade de registro de informações, qualquer que seja o suporte ou formato".

Araújo Júnior, Sousa e Albuquerque (2015, p. 45) destacam a importância dos procedimentos envolverem "a produção, tratamento técnico e preservação dos acervos arquivísticos e informacionais" e que os mesmos "devem estar dispostos de modo a possibilitar a sua recuperação para atender as demandas informacionais da sociedade". Os autores destacam, ainda, os desafios tecnológicos, relacionados à introdução do documento eletrônico, profusão de bases de dados, abertos e restritos, a dispersão da informação, quantidade de informação não-estruturadas que se apresentam disponíveis na rede mundial de computadores (internet) a qualquer momento. Há também o despreparo dos gestores públicos no que diz respeito a cultura da organização da informação o que resulta numa "análise superficial para subsidiar os processos de avaliação e de tomada de decisão" (ARAÚJO JÚNIOR; SOUSA; ALBUQUERQUE, 2015, p. 49).

No caso dos Correios, somam-se a todos os problemas aqui citados, a cultura do sigilo, fomentada pelo governo militar, e a lógica empresarial presente na prática dos gestores, destaca nos tópicos anteriores através dos autores Teixeira (2013) e Bovo (1997). 
Zepeda (2012, p. 14) destaca que os segredos do poder se estabelecem dentro e fora do poder político que "hierarquizam as pessoas em relação com a prática política" e com a qualidade dos "conhecimentos e argumentos que podem ter a sua disposição". Nos Correios o poder estava na mão do restrito grupo que tinha acesso às informações e determinava, assim, o pequeno círculo dos que ocupavam as principais funções de direção da empresa. Um cenário que começou a mudar depois da LAI.

A descrição física e de conteúdo envolve processos específicos inseridos na cadeia de informação (ou ciclo de vida da informação) cujos componentes são: criação, disseminação, organização, armazenamento e uso. A implantação da LAI vem demonstrando a premente necessidade da organização da informação, e algumas medidas foram adotadas, e o estudo proposto teve o objetivo de trazer elementos a esta premissa.

O Instituto Brasileiro de Governança Corporativa [200-?] identifica como princípios básicos da Governança Corporativa a transparência, onde considera mais do que a obrigação de informar deve ser o" desejo de disponibilizar às partes interessadas informações que sejam de seu interesse e não apenas aquelas impostas por dispositivos legais ou regulamentos".

Araújo Júnior, Souza e Albuquerque destacam o interesse no tema pelos tomadores de decisão, saindo do círculo dos profissionais da área.

Antes o interesse por estudos relativos aos processos de busca e recuperação de informação estava circunscritos alguns grupos de profissionais, notadamente arquivistas e bibliotecários, mas hoje permeiam as preocupações dos tomadores de decisão, bem como dos formuladores de políticas empresariais e dos responsáveis por prestar informações às comunidades específicas, ou a sociedade em geral. (ARAÚJO JÚNIOR; SOUSA; ALBUQUERQUE, 2015, P.65).

A ECT produz uma grande quantidade de informações/documentos, pela natureza de suas atividades, seu porte e abrangência nacional. A infraestrutura postal exerce uma grande influência no crescimento e desenvolvimento do Brasil junto à população, distribuída nos 5.570 municípios do País ${ }^{14}$. Para tanto, os Correios possuem ${ }^{15} 6.315$ agências próprias e 1.002 franqueadas, 4.304 comunitárias, entre outras, totalizando mais de 11 mil unidades de atendimento ${ }^{16}$. Com essa estrutura e com o empenho de cerca 105 mil empregados, os Correios

\footnotetext{
${ }^{14}$ Dados IBGE. Disponível em https://cidades.ibge.gov.br/brasil/panorama. Acesso em 22.set.2019.

15 Na publicação da dissertação em 2016, eram 120mil empregados.

16 Principais números dos Correios, publicado em junho de 2018. Disponível em http:/www.correios.com.br/sobre-oscorreios/a-empresa/quem-somos/principais-numeros. Acesso em 22.set.2019.
} 
entregaram, em 2018, mais de 1 milhão de objetos por dia $^{17}$. Entretanto, não se adotava um padrão de gestão documental tão necessário a organização das informações geradas e sob custódia da empresa e que cada brasileiro reconhece como pública, e exige como serviço público.

No processo de sensibilização dos empregados da empresa, para adoção da nova sistemática de gestão documental, foi apresentada, como justificativa para as mudanças, a necessidade de transparência, de publicidade dos atos administrativos, da defesa da probidade administrativa, do controle de toda a tramitação dos documentos e, sobretudo, da segurança para quem trabalha corretamente. Com a entrada em vigor da LAI, em maio de 2012, a organização da informação passava a ser vital para o cumprimento da lei.

Tal iniciativa fomentou o processo de mudança cultural e o aprimoramento da gestão documental de maneira mais ampla, proporcionando condições favoráveis de transparência, segurança, controle e, consequentemente, maior eficácia da gestão, além do alinhamento dessa ação com os princípios constitucionais da legalidade, publicidade e eficiência. A concretização desta política, traçada em 2011, foi publicada na Portaria CONARQ n ${ }^{\circ}$ 258/2016 ${ }^{18}$, de 13 de outubro, na qual o Diretor-Geral do Arquivo Nacional aprova, pelo prazo de 24 (vinte e quatro) meses, o Código de Classificação e a Tabela de Temporalidade e Destinação dos Documentos de Arquivo relativos às atividades-fim da ECT.

Da nova sistemática de Gestão Documental à adoção das normas de arquivamento e descarte de documentos previstas na Lei de Arquivo, a empresa avançou para a gestão eletrônica de documentos com a adesão ao Sistema Eletrônico de Informações ${ }^{19}$ (SEI), sob a responsabilidade da GDOC $^{20}$. Podemos afirmar que uma "revolução" se iniciou em matéria de organização da informação na empresa.

\section{IMPLANTAÇÃO DA LAI NOS CORREIOS}

Em 2012, a partir da Presidência da República, especificamente da CGU, uma série de orientações foram enviadas, através de ofícios diretamente ao Presidente da ECT, determinando

\footnotetext{
${ }^{17}$ Relatório Integrado dos Correios 2018. Disponível em http://www.correios.com.br/sobre-os-correios/a-empresa/publicacoes /processos-de-contas-anuais/pdf/2019/relato-integrado-dos-correios-2013-exercicio-2018. Acesso em 22.set.2019.

${ }^{18}$ Diário Oficial da União no 200, de 18 de outubro de 2016, Seção I, p. 19.

${ }^{19}$ O Sistema Eletrônico de Informações (SEI!), desenvolvido pelo Tribunal Regional Federal da $4^{\text {a }}$ Região (TRF4), é uma plataforma que engloba um conjunto de módulos e funcionalidades que promovem a eficiência administrativa.

${ }^{20}$ Em função das diversas reestruturações realizadas na ECT, esta gerência não mais existe, as atividades de gestão documental estão sob a responsabilidade da Diretoria de Administração (DIRAD).
} 
o passo-a-passo a ser seguido para garantir que toda a administração pública cumprisse fielmente a Lei de Acesso à Informação.

O Presidente da ECT instituiu o Grupo de Trabalho (GT) ${ }^{21}$, em abril de 2012, com representantes de todas as áreas da empresa, incumbido de cumprir cada etapa determinada na planilha de execução enviada pelo órgão de controle. Além da CGU, o Departamento de Coordenação e Governança das Empresas Estatais (DEST), vinculado ao Ministério do Planejamento (MP), e o Ministério das Comunicações (MC) acompanhavam semanalmente os andamentos. O checklist envolvia desde o levantamento e organização das informações, e desenvolvimento da página de acesso à informação na internet, às regras para classificação de informação. Através de despacho do Presidente da ECT, foi designado o Chefe da Ouvidoria, Sr. Lucio da Silva Santos para exercer a função de Autoridade de Monitoramento da $\mathrm{LAI}^{22}$ e esta autora como sua suplente.

O GT aprovou a adoção de uma estrutura de tramitação dos pedidos de informação e dos recursos que garantisse a hierarquia preconizada pela LAI (art. 15), e estabelecida pelo art. 21 do Decreto $n^{0} 7.724$ (BRASIL, 2012a). Uma rede de representantes do Serviço de Informação ao Cidadão (SIC) foi constituída por cada Vice-Presidência, Departamento e Diretoria Regional, e da Presidência, que foram denominados de "Pontos Focais do SIC" e passaram a ser o elo de ligação do SIC com a estrutura da empresa. Os Pontos Focais são empregados designados pelas autoridades que assinam as respostas dos pedidos de informação e recursos. Para cada órgão foi criada uma caixa postal de email onde as demandas recebidas pelo sistema e-SIC eram encaminhadas em meio eletrônico. Aos Pontos Focais coube a responsabilidade de identificar o setor com gestão sobre a informação solicitada e devolver, no prazo estabelecido, ao SIC-ECT. Através de um ambiente colaborativo e de transparência dos pedidos e das respostas, desenvolvido no âmbito da intranet da empresa, foi possível um maior diálogo entre pontos focais e gestores que buscava o aprimoramento do atendimento ao cidadão. A partir deste modelo foi possível desenvolver respostas padrões, garantir tratamento equânime da empresa para os cidadãos, resolução de conflitos e o uso do bom senso no atendimento as demandas recebidas.

Os relatórios estatísticos com os pedidos de informação e recursos são de acesso público à todos os cidadão, e estão disponíveis no sistema e-SIC. No processo de implantação da LAI nos Correios foi estabelecido que o pedido inicial é respondido em primeiro nível por

\footnotetext{
${ }^{21}$ GT implantação da LAI - Portaria n ${ }^{\circ}$ 32, de 24 de abril de 2012. Publicada no D.O.U no 82, de 27/04/2012, Seção 2, p.40.

${ }^{22}$ Designação da Autoridade de Monitoramento da LAI na ECT, publicado no D.O.U no 87, de 7/05/2012, Seção 2, p.45.
} 
um chefe de Departamento ou Diretor Regional; o Recurso de $1^{\mathrm{a}}$ Instância é respondido pelo Vice-Presidente gestor do assunto abordado, ou Chefe de Gabinete da Presidência ou Superintende Executivo (estes vinculados à Presidência), o Recurso de $2^{\text {a }}$ Instância pelo Presidente da empresa. O Decreto $n^{\circ} 7.724 / 2012$ determina ainda que os Recursos de $3^{\mathrm{a}}$ Instância são diretamente encaminhados à CGU e os de $4^{\mathrm{a}}$ à $\mathrm{CMRI}^{23}$.

A seguir no Gráfico 1 podemos observar que $80 \%$ dos 6.773 pedidos de informação registrados no SIC - ECT, de maio de 2012 a dezembro de 2015, tiveram acesso concedido.

Gráfico 1 - Respostas aos Pedidos de Informação - ECT ${ }^{24}$

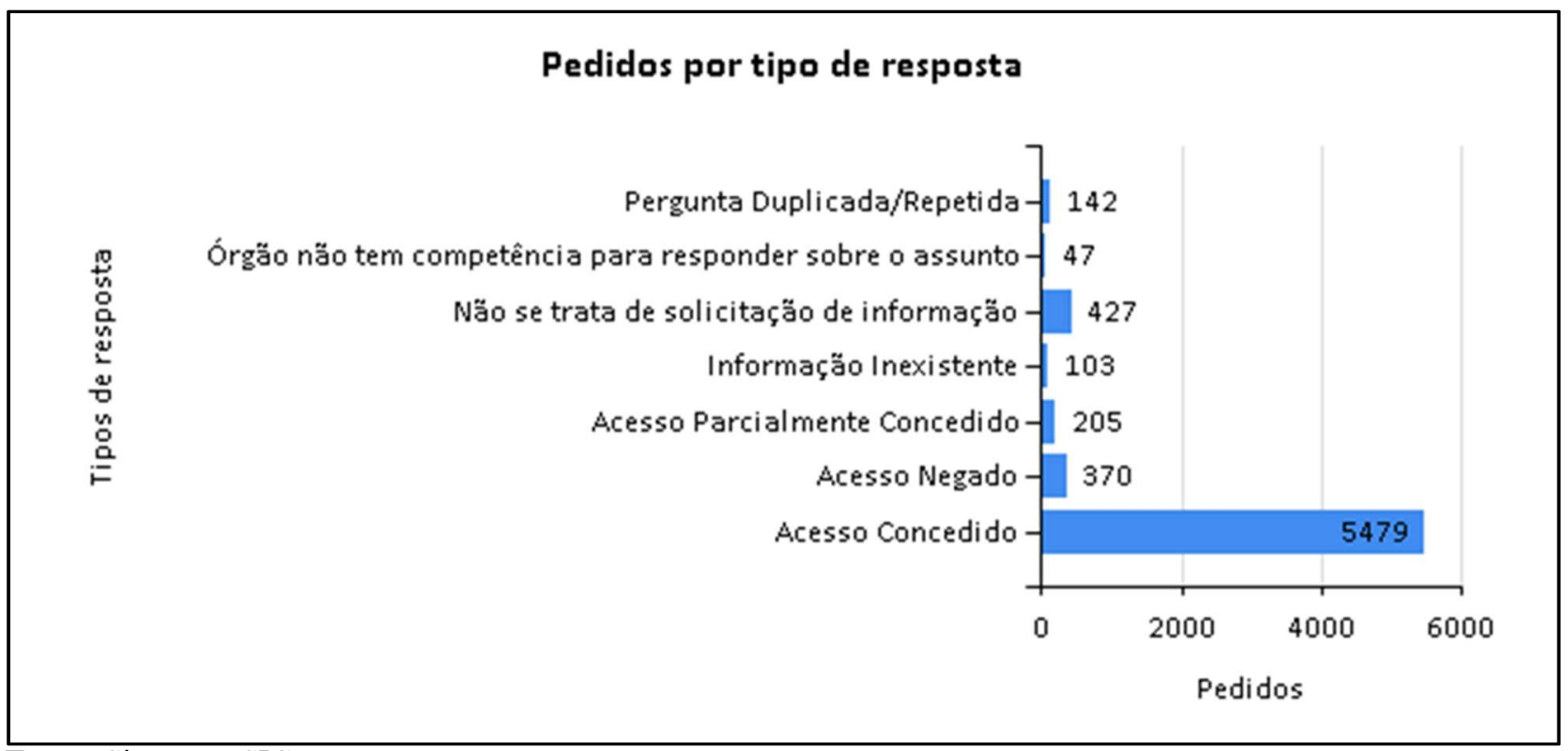

Fonte: Sistema e-SIC

A ECT recebeu, no período de 16 de maio de 2012 à 31 de dezembro de 2015, 6.773 pedidos de informação registrados no sistema e-SIC. De acordo com as respostas dos gestores 5.479 tiveram acesso concedido, representando $80 \%$ dos pedidos. Na análise geral, verificamos que apenas 129 pedidos não foram atendidos no âmbito da empresa e seguiram para a $3^{\mathrm{a}}$ Instância (CGU). O reduzido número reflete o esforço do SIC-ECT em atender ao cidadão ${ }^{25}$,

\footnotetext{
${ }^{23}$ Comissão Mista de Reavaliação de Informações, criada pelo $\S 1^{\circ}$ do Art. 35 da Lei 12.527/2011.

${ }^{24}$ Período do estudo e do gráfico: maio de 2012 à dezembro de 2015. Disponível em https://esic.cgu.gov.br/sistema/Relatorios/ Anual/RelatorioAnualPedidos.aspx. Acesso em 22.set.2019.

${ }^{25}$ Após maio de 2016 (afastamento da Presidenta Dilma Roussef) a ECT, como vários órgãos, passaram por várias mudanças e novos estudos apontam retrocessos no processo de acesso à informação. Na ECT, os pedidos de informação no período de junho de 2016 à junho de 2019 aumentaram de 6.773 (2012/2015) para 9.300(2016/2019), entretanto apenas 26\% dos pedidos foram concedidos.
} 
portanto, os pedidos que chegaram a CGU revestem-se de questionamentos quanto a aplicação da lei e dos argumentos de sigilo comercial, em função da atividade concorrencial.

Destacamos dois casos que expõem o problema objeto deste estudo, em que questionamos de que maneira a condição de empresa híbrida dos Correios influi na aplicação da LAI quanto à transparência das informações. E como a cultura organizacional dos Correios influenciou na organização e acesso às suas informações após a promulgação da LAI.

Caso 1: Código de Endereçamento Postal

Pedido de Informação: 99923.000436/2013-87

em que requer lhe seja fornecido o cadastro completo de CEPs (CEPs dos Municípios/Localidades, Faixa de CEP, CEP Especiais, Logradouros, etc), última atualização disponível, em arquivos texto, banco de dados MS Access ou planilha MS Excel.

A ECT respondeu com o tipo de resposta "acesso negado" informando que o e-DNE é um produto comercializado pela ECT por meio da Correios Online e que "a informação de forma individualizada se encontra disponível, por meio do Busca CEP, no site www.correios.com.br", pelo qual qualquer cidadão pode consultar gratuitamente o CEP. A ECT alegou ainda, que o e-DNE é considerado obra intelectual nova e original, nos termos da Lei. 9.610/1998 (Lei de Direitos Autorais), sob titularidade da empresa. A empresa informou que “depositou e é legitima titular perante o Instituto Nacional de Propriedade Industrial (INPI) do pedido de Patente de Invenção [...], titulado 'Diretório Nacional de Endereços (DNE)' e perante o German Patent Applicatations, depositou e é legitima titular da extensão da patente de invenção". Após as seguidas negativas de acesso pela ECT, o cidadão interpôs recurso à CGU.

No parecer do Ouvidor-Geral da União (OGU), assinado também por dois Analistas de Finanças e Controle da CGU, há uma desconstrução da resposta da empresa. Nele os técnicos analisam a Lei de Patentes e argumentam que o conteúdo de banco de dados não é objeto patenteável e, caso tal ocorra, "poderá vir a ser objeto de declaração de nulidade, por força do art. 46 da Lei 9.279/1996”. Destaca ainda que o depósito de pedido de patente não gera senão a expectativa de um direito, a ser ou não confirmado mediante a outorga da carta patente, e não tem o poder de configurar hipótese legal de sigilo. O parecer faz ainda uma análise histórica do CEP quanto à sua natureza pública, quando foi desenvolvido em substituição às Zonas Postais ou Zonas de Correio, criadas pelo DCT. Com a publicação do Decreto-Lei 509/1969, todo 
capital proveniente da União, que estava a serviço ou disposição do DCT passou à ECT e que ao longo destas quase cinco décadas o CEP passou a ser usado em todo território nacional, estando em placas sinalizadoras de logradouros na maioria dos munícipios brasileiros. A CGU questiona o fato da ECT nunca ter impedido que os mesmos fossem divulgados. Na avaliação da CGU tal comportamento da empresa é de que a informação era de interesse público e devia ser divulgada. Destacaram ainda, o fato da lista (em papel), com o registro agregado dos CEP, ser disponibilizada em toda agência da ECT e que ficava ao alcance do cidadão. O que é uma realidade na lembrança de todos os brasileiros, até a década de 1990. A CGU analisa ainda os artigos da CF que determinam ser de competência da União manter o serviço postal e o correio aéreo nacional.

\begin{abstract}
Em outras palavras, situa-se o desenvolvimento e atribuição de indexação a logradouros verdadeiro serviço público uti universi, que, apesar de servir ao bom desempenho da atividade econômica, com ela não se confunde. Se, portanto, a informação individualizada não pode ser considerada sigilosa ou privada, tampouco o poderá, pelos motivos expostos, a informação agregada na base de dados. (BRASIL, [2013], p. 10).
\end{abstract}

Entretanto, a CGU entendeu que tendo o CEP foi criado logo após ter se transforma em empresa estatal de direito privado, e portanto com direito autoral sobre o produto, identificou "a antinomia como conflito real entre o art. 5', inciso XXXIII da Constituição, combinado com o art. 12 da Lei 12.527/2011 e o art. 5, caput e incisos XXII e XXVII e art. 173, $\S 1^{\circ}$, II da Constituição Federal, combinados com o art. $3^{\circ}$ da Lei 9.610/1998”. (BRASIL, [2013], p. 18). O Recurso foi então encaminhado para consulta à Comissão Mista de Reavaliação de Informação (CMRI) que orientou a análise do recurso à luz da Lei n ${ }^{\circ}$ 6538/1975 - a Lei Postal. Nesse sentido a CGU indeferiu o pedido de informação.

A base de dados do CEP é informação frequentemente solicitada, e sua disponibilização é assunto polêmico inclusive no interior da empresa. A área gestora do e-DNE, responsável pela área de logística e produtos comercializados, defende a posição de restrição de acesso que tem sido majoritária. Já a área operacional considera que, para a empresa, seria mais lucrativo sua distribuição gratuita, uma vez que $20 \%$ das devoluções de correspondências advém de erro no CEP, o que traz retrabalho e prejuízos. Entretanto, não foram feitos estudos oficiais, audiências públicas ou qualquer outro movimento para ampliar essa discussão. O cidadão continua apenas com acesso individualizado no "Busca CEP”, disponível na página dos Correios. 
Caso 2: Os 100 maiores salários da DR-Paraná

\section{Pedido de Informação ${ }^{26}$ : NUP 99923.001660/2013-96}

Nome, matrícula dos 100 maiores salários da DR Paraná e dos respectivos salários com todos seus acréscimos definido em lei, referente ao mês de novembro e dezembro 2013.

A questão de divulgação dos salários foi um dos temas que mais esteve presente quando a LAI entrou em vigor. Inúmeras matérias de jornais abordaram o tema e na ECT a resistência foi muito grande. As empresas estatais não estão no Sistema Integrado de Administração de Recursos Humanos (SIAPE) utilizado pela administração direta, autarquia e fundações, que disponibiliza no Portal da Transparência salário bruto e salário líquido. O GT decidiu divulgar a listagem com o nome dos empregados, cargo ocupado, respectiva referência salarial no Plano de Carreira e, no caso de ser ocupante de função, a denominação. Também divulgou as tabelas salariais e de funções.

A ECT inicialmente respondeu com "acesso negado" alegando que exigia trabalhos adicionais de análise, interpretação e consolidação dos dados e informações, e que de acordo com o art. 13 do Decreto 7.724/2012, regulamenta a LAI, não é atribuição da empresa e que teria que pedir autorização dos envolvidos, além de alegar tratar de dados pessoais. O trabalho adicional seria pelo fato de ter que separar o Paraná da relação geral e selecionar os 100 maiores. O solicitante registra recurso onde explicita o art. $7^{\circ}, \S 3^{\circ}$, inciso VI, do Decreto $7724 / 2012$ que prevê a divulgação, de forma individualizada, da remuneração e subsídios recebidos por ocupantes da gestão pública, inclusive de emprego público. A empresa mantém a negativa, mas envia a lista de todos os empregados lotados na DR-PR e orienta a localizar na listagem que está na internet os nomes e as tabelas salarias divulgadas. O cidadão registra novo recurso agora dirigido ao Presidente da empresa e, mais uma vez, sem sucesso. A CGU ao receber o recurso buscou agir como intermediadora entre o cidadão e a ECT, solicitando informações adicionais à empresa. A ECT alega que as empresas públicas não estão obrigadas a publicar no Portal da Transparência Pública, de acordo com a Portaria Interministerial no 233 (BRASIL, 2012b), de $25 / 05 / 2012$.

No Parecer n 2979 de 24/07/2014 ${ }^{27}$, a CGU afirma que a ECT seria obrigada a disponibilizar, em transparência ativa, a remuneração de todos os seus empregados públicos,

\footnotetext{
${ }^{26}$ NUP - Protocolo do pedido de informação - Parecer CGU. Disponível em http://buscaprecedentes.cgu.gov.br/busca/ dados/Precedente/99923001660201396_CMRI.pdf\#search=99923\%2E001660\%2F2013\%2D96. Acesso em 22.set.2019.

${ }^{27}$ Idem 23.
} 
incluindo seus diretores, conforme os dispositivos legais. A instância recursal também não aceita a alegação de tratamento de dados para este pedido devendo, a empresa, informar o prazo necessário para produzir, uma vez que é sua competência legal e que não há nenhuma informação pessoal que prejudique a vida privada, a honra, a imagem, a intimidade ou que causem prejuízos de ordem moral. Entretanto, ao final afirma que o acesso à informação "passa pela discussão sobre a natureza concorrencial" da ECT. Alega a CGU, que a ECT atua em atividade essencialmente econômica, mesmo tendo o monopólio postal o que evidencia o "caráter hibrido em que a empresa atua no mercado". Portanto, ao considerar que a ECT não pode ser caracterizada apenas como prestadora de serviços públicos, "não está obrigada a seguir integralmente as hipóteses do inciso VI, do parágrafo $3^{\circ}$, do artigo $7^{\circ}$, do Decreto $\mathrm{n}^{\circ} 7.724 / 11$ e da Portaria Interministerial $n^{\circ} 233 "$.

\section{CONSIDERAÇÕES FINAIS}

O entendimento das empresas estatais, e da CGU, é que o caráter hibrido, justifica a negativa de acesso à informação aos cidadãos. Com isso a ECT não estaria obrigada a atender pedidos de informação que possam afetar sua vantagem competitiva e comprometer sua estratégia empresarial. A lógica empresarial também trouxe seus efeitos na organização da informação na década de 1990, possibilitando um distanciamento da empresa das práticas típicas da administração pública. Lógica que se mostrou equivocada, não sobreviveu ao processo do inquérito civil do MPF e acarretou para a empresa uma imagem negativa.

Bento e Bringel (2014, p.378) ao analisar os limites à transparência pública das empresas estatais, apontam "o uso indiscriminado de sigilo comercial e bancário para não fornecerem as informações", destacando que as mesmas secundarizam o fato de que o acesso à informação é "instrumento imprescindível para coibir o conflito de interesses, a corrupção e o desvio de recursos dessas entidades".

A ECT é uma empresa pública em que a União é a única acionista. O STF confirmou o monopólio postal, que lhe garante isenções fiscais, e tem características, como as destacadas pelo Ministro Carlos Ayres Britto (BRASIL, 2010) fundamentais à sociedade democrática. As garantias para a comunicação privada entre pessoas, a integração nacional e o sigilo da correspondência. O CEP, mecanismo de organização espacial, necessário para projetos de georreferenciamento e para o desenvolvimento das pequenas e médias empresas, até este 
momento não está com sua base de dados disponível para os cidadãos. A CGU reconhece que é uma informação pública e não propriedade comercial da ECT, mas que continua sendo negada. Estes foram apenas alguns aspectos que estão presentes em nosso estudo, que inclui a análise da pesquisa de satisfação dos cidadãos e aplicação de questionário aos Pontos Focais, sobre como enxergam a organização da informação na empresa (RIBEIRO, 2016).

A Lei de Responsabilidade das Estatais, Lei 13.303 (BRASIL, 2016), apresenta vários mecanismos de transparência e governança, especificando a divulgação de várias informações das empresas, que, esperamos, possam contribuir com uma mudança de postura mais efetiva.

Ao destacar a organização e o acesso à informação na ECT buscamos contribuir com a sociedade brasileira no controle social de nossas empresas estatais e na sua sustentabilidade. A ECT tem sua peculiaridade na importância que ocupa na política de informação e comunicação do Brasil. Uma maior transparência e democratização na sua gestão é o caminho para manter sua supremacia no serviço e mercado postal que desejamos que continue pública à serviço da sociedade brasileira. 


\section{REFERÊNCIAS}

ARAÚJO, Carlos Alberto Ávila. Arquivologia, Biblioteconomia, Museologia e Ciência da Informação: o diálogo possível. Brasília, DF: Briquet de Lemos; São Paulo: Associação Brasileira de Profissionais da Informação (ABRAINFO), 2014.

ARAÚJO JÚNIOR, Rogério Henrique de; SOUSA, Renato Tarciso Barbosa de; ALBUQUERQUE, Sérgio Farias de. Métodos, técnicas e instrumentos de organização e gestão da informação nas organizações. In: BAPTISTA, Dulce Maria; ARAÚJO JÚNIOR, Rogério Henrique de (org.). Organização da informação: abordagens e práticas. Brasília: Thesaurus, 2015. p. 44-68.

BARACCHINI, A, P. O sigilo dos arquivos vinculados ao regime militar e o direito constitucional à informação: uma questão de cidadania. Revista Eletrônica do Curso de Direito da UFSM, Santa Maria, v. 3, n. 2, p. 120-133, jun.2008. Disponível em: $<$ http://periodicos.ufsm.br/revistadireito/article/view/6862\#.V5YBIrgrLIU $>$. Acesso em: 22 set. 2019.

BENTO, Leonardo Valles; BRINGEL, Polyana de Oliveira Martins. Limites à transparência pública das empresas estatais: análise crítica da aplicação da Lei de Acesso a Informação (Lei $n^{0}$ 12.527/2011) a Empresas Públicas e Sociedades de Economia Mista. Direito e administração pública I [Recurso eletrônico on-line] organização CONPEDI/UFPB, - Florianópolis: CONPEDI, 2014, pag. 356 - 383. Disponível em: $<$ http://www.publicadireito.com.br/artigos/?cod=c139ffc26fbaf2d1>. Acesso em 19 set. 2019.

BOBBIO, Norberto. Democracia e Segredo. Organização: Marco Revelli. Tradução Marco Aurélio Nogueira. São Paulo: Ed. Unesp, 2015.

BOBBIO, Norberto. Nem com Marx, Nem contra Marx. Organização: Carlo Violi. Tradução: Marco Aurélio Nogueira. São Paulo: Ed. UNESP, 2006.

BOURDIEU, Pierre. Sobre o Estado: Cursos no Collège de France (1989-92). Tradução: Rosa Freire d'Aguiar. São Paulo: Companhia das Letras, 2014.

BOVO, Cassiano Ricardo Martines. Os Correios no Brasil e a Organização Racional do Trabalho. São Paulo: Annablume, 1997. Disponível em: $<$ https://books.google.com.br/books?id=7Oc5G-lsRegC\&printsec=frontcover\&hl=pt-

PT\&source $=$ gbs_ge_summary_r\&cad $=0 \# v=$ onepage $\& q \& f=$ false $>$. Acesso em: 20 set. 2019.

BRASIL. [Constituição (1988)]. Constituição da República Federativa do Brasil de 1988. Brasília, DF: Presidência da República, [1988]. Disponível em: $<$ http://www.planalto.gov.br/ccivil_03/Constituicao/Constituiçao.htm>. Acesso em: 19 set. 2019.

Controladoria Geral da União. Cartilha de Acesso a Informação. Brasília: CGU, 2011a. Disponível em: <http://www.acessoainformacao.gov.br/central-deconteudo/publicacoes/arquivos/cartilhaacessoainformacao.pdf $>$. Acesso em: 19 set. 2019. 
Controladoria Geral da União. Parecer Referência 99923.000436/2013-87. Recurso interposto por cidadão à CGU contra decisão denegatória de acesso à informação, com fundamento no art. 23 do Decreto no 7.724, de 16 de maio de 2012. Brasília: CGU, [2013]. Disponível em:

$<$ http://buscaprecedentes.cgu.gov.br/busca/dados/Precedente/99923000436201387_CGU.pdf\# search $=99923 \% 2 \mathrm{E} 001172 \% 2 \mathrm{~F} 2012 \% 2 \mathrm{D} 06>$. Acesso em: 22 set. 2019.

Decreto $\mathbf{n}^{\mathbf{0}} \mathbf{7 . 7 2 4}$, de 16 de maio de 2012. Regulamenta a Lei no 12.527 , de 18 de novembro de 2011. Brasília, DF: Presidência da República, 2012a. Disponível em: $<$ http://www.planalto.gov.br/CCIVIL_03/_Ato2011-2014/2012/Decreto/D7724.htm>. Acesso em: 20 set. 2019.

. Decreto-Lei $n^{0}$ 200, de 25 de fevereiro de 1967. Dispõe sobre a organização da Administração Federal, estabelece diretrizes para a Reforma Administrativa e dá outras providências. Brasília, DF: Presidência da República, 1967. Disponível em: <http://www.planalto.gov.br/ccivil_03/decreto-lei/del0200.htm>. Acesso em: 20 set. 2019.

. Decreto-Lei no 509, de 20 de março de 1969. Brasília, DF: Presidência da República, 1969. Disponível em: <http://www.planalto.gov.br/ccivil_03/decreto-lei/Del0509.htm>. Acesso em: 20 set. 2019.

Lei $n^{0}$ 6.404, de 15 de dezembro de 1976. Dispõe sobre as Sociedades por Ações. Brasília, DF: Presidência da República, 1976. Disponível em: $<$ http://www.planalto.gov.br/ccivil_03/leis/16404consol.htm>. Acesso em: 20 set. 2019.

Lei $n^{0}$ 6.538, de 22 de junho de 1978. Lei Postal. Brasília, DF: Presidência da República, 1978. Disponível em: <http://www.planalto.gov.br/ccivil_03/LEIS/L6538.htm>. Acesso em: 20 set. 2019.

Lei no 8.159, de 8 de janeiro de 1991. Lei de Política Nacional de Arquivos Públicos e Privados. Brasília, DF: Presidência da República, 1991. Disponível em: $<$ http://www.planalto.gov.br/ccivil_03/Leis/L8159.htm>. Acesso em: 20 set. 2019.

Lei $n^{0}$ 8.666, de 21 de junho de 1993. Regulamenta o art. 37, inciso XXI, da Constituição Federal, institui normas para licitações e contratos da Administração Pública e dá outras providências. Brasília, DF: Presidência da República, 1993. Disponível em: $<$ http://www.planalto.gov.br/ccivil_03/LEIS/L8666cons.htm>. Acesso em: 20 set. 2019.

Lei no 9.784, de 29 de janeiro de 1999. Regula o processo administrativo no âmbito da Administração Pública Federal. Brasília, DF: Presidência da República, 1999. Disponível em <http://www.planalto.gov.br/ccivil_03/leis/19784.htm>. Acesso em: 20 set. 2019.

. Lei no 12.490, de 16 de setembro de 2011. Altera artigos do Decreto-Lei 509/1967 e outros. Brasília, DF: Presidência da República, 2011b. Disponível em: $<$ http://www.planalto.gov.br/ccivil_03/_Ato2011-2014/2011/Lei/L12490.htm>. Acesso em: 20 set. 2019.

. Lei $\mathbf{n}^{0}$ 12.527, de 18 de novembro de 2011. Lei de Acesso à Informação. Brasília, DF: Presidência da República, 2011c. Disponível em: 
$<$ http://www.planalto.gov.br/ccivil_03/_Ato2011-2014/2011/Lei/L12527.htm>. Acesso em: 20 set. 2019.

Lei n⿳ 13.303, de 30 de junho de 2016. Lei de Responsabilidade das Estatais. Brasília, DF: Presidência da República, 2016. Disponível em: $<$ http://www.planalto.gov.br/ccivil_03/_ato2015-2018/2016/lei/113303.htm>. Acesso em: 20 set. 2019.

Portaria Interministerial $\mathbf{n}^{0}$ 233, de 25 de maio de 2012. Disciplina, no âmbito do Poder Executivo federal, o modo de divulgação da remuneração e subsídio conforme disposto no inciso VI do $\S 3^{\circ}$ do art. $7^{\circ}$ do Decreto $\mathrm{n}^{\circ} 7.724$, de 16 de maio de 2012. Brasília, DF: Ministério do Planejamento, Orçamento e Gestão, 2012b. Disponível em: $<$ https://www.normas.gov.br/materia/-/asset_publisher/NebW5rLVWyej/content/id/24712255 >. Acesso em: 20 set. 2019.

Portaria Interministerial $\mathrm{n}^{\mathrm{o}} 1.254$, de 18 de maio de 2015. Institui o Sistema Eletrônico do Serviço de Informação ao Cidadão (e-SIC) no âmbito do Poder Executivo federal. Diário Oficial da União: seção 1, Brasília, DF, ano 152, n. 93, p. 1, 19 maio 2015. Disponível em: $<$ http://www.acessoainformacao.gov.br/assuntos/legislacao-relacionada-1/cgu-prt-inter1254.pdf>. Acesso em: 20 set. 2019.

Supremo Tribunal Federal. Arguição de Descumprimento de Preceito Fundamental 46 -7 Distrito Federal (ADPF 46/DF). Relator: Min. Marco Aurélio; Relator para o Acordão: Min Eros Grau, 05 de agosto de 2009. Brasília, DF: STF, 26 fev. 2010. Disponível em: $<$ http://redir.stf.jus.br/paginadorpub/paginador.jsp?docTP $=\mathrm{AC} \&$ docID $=608504>$. Acesso em: 20 set. 2019.

BRESSER-PEREIRA, Luiz Carlos Bresser. Da administração pública burocrática à gerencial. Revista do Serviço Público, Brasília, ano 47, v. 121, n. 1, jan./abr. 1996.

BRESSER-PEREIRA, Luiz Carlos Bresser. Uma reforma gerencial da Administração Pública no Brasil. Revista do Serviço Público, Brasília: ENAP, ano 49, n. 1, jan./mar. 1998.

BROOKES, B.C. The foundations of information Science: part I philosophical aspects. Journal of Information Science, [S.1.], n. 2, p. 125-133, 1980.

CARNOY, Martin. Gramsci e o Estado. In. CARNOY, Martin. Estado e Teoria política. 3. ed. Campinas: Papirus, 1988. p. 89-118. Disponível em: $<$ http://www.ie.ufrj.br/intranet/ie/userintranet/hpp/arquivos/071120163334_MartinCarnoyEst adoeTeoriaPolItical capitulo3pdf.pdf>. Acesso em: 19 set. 2019.

CARVALHÊDO, Shirley do Prado; RODRIGUES, Georgete. A política de informação orgânica no regime militar brasileiro: os arquivos da Guerrilha do Araguaia (1972-1974). In: ENCONTRO NACIONAL DE PESQUISA EM CIÊNCIA DA INFORMAÇÃO, 9., 2008, São Paulo. Anais [...]. São Paulo: USP, 2008. Disponível em: $<$ http://repositorios.questoesemrede.uff.br/repositorios/handle/123456789/1625>. Acesso em: 25 set. 2019. 
CUNHA FILHO, Marcio Camargo; XAVIER, Vitor César Silva. Lei de Acesso à informação: teoria e prática. Rio de Janeiro: Lumen Juris, 2014.

CURY, Vania Maria. História da Industrialização no Século XIX. Rio de Janeiro: Ed. UFRJ, 2006. (Séries Didáticos).

DAGNINO, Renato; COSTA, Greiner (org.). Gestão Estratégica em Políticas Públicas. Campinas, SP: Alínea, 2013.

FERNANDES, Ananda Simões. A perseguição além da fronteira: os órgãos de repressão e espionagem da ditadura brasileira para o controle dos exilados brasileiros no Uruguai. Estudios historicos - CDHRP, [S.1.], n. 1, mayo 2009. Disponível em: $<$ http://www.estudioshistoricos.org/edicion_1/ananda-simoes.pdf $>$. Acesso em: 22 set. 2019.

FONSECA, Maria Odila. Arquivologia e Ciência da Informação. Rio de Janeiro: Ed. FGV, 2013.

FREIRE, Paulo. Educação e Mudança. Rio de Janeiro: Paz e Terra, 1983. (Educação e Mudança, v. 1).

FROHMANN, Bernd. O caráter social, material e público da informação. In: FUJITA, Mariangela Spotti Lopes; MARTELETO, Regina Maria; LARA, Marilda Lopes Ginez de (org.) A dimensão epistemológica da Ciência da Informação e suas interfaces técnicas, políticas e institucionais nos processos de produção, acesso e disseminação da informação. São Paulo: Cultura Acadêmica, 2008.

GRAMSCI, A. Introdução à Filosofia da Práxis. Lisboa: Antídoto, 1979.

INSTITUTO BRASILEIRO DE GOVERNANÇA CORPORATIVA. Princípios que geram valor a longo prazo. São Paulo: IBGC, [200-?]. Disponível em: $<$ https://www.ibgc.org.br/conhecimento/governanca-corporativa $>$. Acesso em: 22 set.2019

JARDIM, José Maria. Transparência e Opacidade do estado no Brasil: usos e desusos da informação governamental. Niterói: Ed. UFF, 1999.

KLERING, Luis Roque; PORSSE, Melody de Campos Soares; GUADAGNIN, Luís Alberto. Novos Caminhos da Administração Pública Brasileira. Revista Análise, Porto Alegre, v. 21, n. 1, p. 4-17, jan./jun. 2010. Disponível em: <http://revistaseletronicas.pucrs.br/fo/ojs/index.p hp/face/article/view/8231>. Acesso em: 22 set. 2019.

LEITE, Paulo Moreira. A Outra História do Mensalão: as contradições de um julgamento político. São Paulo: Geração Editorial, 2013.

MALIN, Ana Maria Barcellos. Reflexões sobre a adesão brasileira ao regime global de acesso à informação pública. In: ENCONTRO NACIONAL DE PESQUISA EM CIÊNCIA DA INFORMAÇÃO, 13., 2012, Rio de Janeiro. Anais [...]. Rio de Janeiro: FIOCRUZ, 2012. Disponível em: <https://obgi.files.wordpress.com/2012/10/reflexc3b5es-sobre-a-adesc3a3obrasileira-ao-regime-global-de-acesso-c3a0-informac3a7c3a3o-pc3bablica.pdf $>$. Acesso em: 22 set. 2019. 
MALIN, Ana; FREITAS, Christiane Soares de. Estado e gestão pública no Brasil: tensões e avanços dos regimes digitais de informação. Revista NAU Social, Bahia, v. 09, n. 17, p. 0412, nov. 2018 / abr. 2019. Disponível em $<$ https://portalseer.ufba.br/index.php/nausocial/article/view/31442>. Acesso em 22 set. 2019.

MANDEL, Ernest. Introdução ao Marxismo. Porto Alegre: Movimento, 1982.

MENDEL, Toby. Liberdade de Informação: um estudo de direito comparado. 2. ed., rev. e atual. Brasília: UNESCO, 2009. Disponível em: $<$ http://www.acessoainformacao.gov.br/central-de-conteudo/publicacoes/arquivos/liberdadeinformacao-estudo-direito-comparado-unesco.pdf>. Acesso em: 22 set. 2019.

NOGUEIRA, Marco Aurélio. Um Estado para a Sociedade Civil: tema éticos e políticos da gestão democrática. 3. ed. São Paulo: Cortez, 2011.

ORGANIZAÇÃO DAS NAÇÕES UNIDAS. Declaração Universal Dos Direitos Humanos. Rio de Janeiro: UNIC, 2009. Disponível em: <https://nacoesunidas.org/wpcontent/uploads/2018/10/DUDH.pdf>. Acesso em: 22 set. 2019.

PORTO JR, Rubem. Exposição/Palestra Censura Postal 1917/1930. São Paulo: [s.n.], 27 set. 2014. 1 vídeo (9 min). Disponível em: <https://www.youtube.com/watch?v=O9TrqQAnY-o >. Acesso em: 22 set. 2019.

RIBEIRO, Ana Maria de A. Organização e acesso à informação na Empresa Brasileira de Correios e Telégrafos após promulgação da Lei de Acesso à Informação. Orientadora: Eliane Braga de Oliveira. 2016. 282 f. Dissertação (Mestrado em Ciência da Informação) Universidade de Brasília, Brasília, DF, 2016. Disponível em: $<$ http://repositorio.unb.br/handle/10482/22921>. Acesso em: 22 set. 2019.

RODRIGUES, Georgete Medleg. Indicadores de "transparência ativa" em instituições públicas: análise dos portais de universidades públicas federais. Liinc em Revista, Rio de Janeiro, v. 9, n. 2, p. 423-438, nov. 2013. Disponível em: <http://www.ibict.br/liinc >. Acesso em: 21 set. 2019.

TEIXEIRA, Tadeu G. Os correios em transformação: reestruturação, organização do trabalho e políticas de gestão do trabalho (1994-2011). 2013. Tese (doutorado em ciências sociais) - Instituto de Filosofia e Ciências Humanas, Universidade Estadual de Campinas, Campinas, 2013. Disponível em: $<$ http://repositorio.unicamp.br/jspui/handle/REPOSIP/280162>. Acesso em: 22 set. 2019.

WERSIG, Gernot; NEVELING, Ulrich. R. The phenomena of Interesting to Information Science. Information Scientist, [S.1.], v. 9, n. 4, p. 127-140, dec. 1975.

ZEPEDA, Jesús Rodríguez. Estado y transparência: um paseo por la filosofia política. Cuadernos de transparência, Instituto Federal de Acesso a la Infomación y Protección de Datos (IFAI), México, n. 4, sep. 2012. Disponível em: $<$ http://inicio.ifai.org.mx/PublicacionesComiteEditorial/Cuadernillo\%2004\%20B.pdf >. Acesso em: 22 set. 2019. 